\title{
Changes in US Global Security Strategy and their Implications for Lithuania
}

\begin{abstract}
Lithuanian membership in NATO and American engagement in Lithuania is part of an increasing American commitment to Northers Europe and the Baltic states. American involvement in our region reflects the changing American grand strategy and threat perception. What implications these changes can have for our region and what decision-makers in Washington expect from new NATO RPU members are the focal points of this article.

The author argues that in order to keep Americans committed, the Baltic states must rethink their foreign and security policy objectives, redefine old priorities and adapt them to the new geostrategic reality.
\end{abstract}

XX century in the world history will be remembered as a century of American hegemony and dominance. The world map in all continents was frequently painted different colours, with only the American continent escaping revolutionary changes. The most powerful country on this continent-the United States of America has been the guarantor of this stability. Its foreign policy remains a synthesis of old traditions and new realities.

The terrorist attacks on September 11 added a new dimension to the American threat perception that could be traced centuries back. For the first time the US was attacked on its own territory and the asymmetrical response became the cornerstone of American strategy. For the very first time after the Cold War, a clear image of the enemy appeared, the new threat was named and huge resources were allocated to fight it. Transformation of US interests, strategic concepts and threat perception resulted in the changing attitude and policy towards many regions and countries, its allies and enemies. ${ }^{1}$

The new American threat perception has a direct impact upon the Lithuanian - American relations. A growing US military assistance and political contacts, NATO enlargement and security guarantees symbolise the evolution of the American policy towards Lithuania. These changes are the subject of a double-sided process. On the one hand, in US global strategy, Europe is no longer perceived as a potential area of instability. New threats to US security come from other parts of the world, and these parts of the world now receive a major attention in Washington.

On the other hand, political, economic and cultural achievements of Lithuania and other countries in the region naturally raise American interest in the region. The US needs allies to preserve its domination in Europe and fight new threats such as terrorism.

\footnotetext{
"Vaidotas Urbelis - Ph. D. candidate, Institute of International Relations and Political Science of the University of Vilnius. Address: Vokiečiu 10, LT-2001 Vilnius, Lithuania, tel. +370-698-11348, e-mail: vaidotas@post.omnitel.net

${ }^{1}$ See: The National Strategy of the United States of America. September 2002.
} 
Changes in US global strategy raise many questions to the academic society and decision-makers around the world - what will be the future of the American involvement in Europe, what role Lithuania and other countries of the region will play in US strategy, what measures they should take in their efforts to preserve American engagement.

The purpose of this article is to reveal and define the place of Lithuania, the Baltic states and regions to which they belong in the US global strategy. Lithuania and its neighbours geostrategically belong to two regions. First of all, they are part of the Northern European region which encompasses the Northern part of the enlarged European Union. At the same time, together with other nations of V10 group, they are bound by the same wish to become members of NATO and to receive American security guarantees. The term Central and Eastern Europe is frequently used to define this set of countries. After NATO membership, this identification will gradually lose ground and at least in the case of the Baltic states, Central European identity will be replaced by Northern identity.

In 2002 the Center for Strategic and International Studies (CSIS) and the Institute of International Relations and Political Science published Lithuania's Security and Foreign Policy White Paper and used the term Baltic-Central Europe. They emphasize that "the Central European and Baltic regions overlap in terms of historical experience, continental identity, cultural continuity, political evolution, and economic development." 2 Baltic-Central Europe, in fact, coincides with Central-Eastern (CE) and Northern Europe with the exception of the north-western part of Russia. Due to a different geopolitical orientation of the northeastern part of Russia and the rest of the Baltic Sea region, the term CE and Northern Europe will be used in this article.

Lithuania's geopolitical orientation has many similar features to that of both Northern and CE European countries. A perspective upon Lithuania as a country belonging to both regions allows us to better define US interests in Lithuania, to relate them to the global US strategy and its regional dimension. The NATO role will be awarded special attention since it remains the most effective tool of the US foreign policy in Europe, the Baltic Sea and the Baltic states.

\section{US Global Security Strategy}

US grand strategy is a combination of both old, as the Monroe doctrine, and new, as fight against terrorism, ideas. Before WWI, US influence upon European affairs was negligible. US resources were minimal, and the political will to interfere into policies of other regions, with the exception of Latin America, was non-existent.

After WWI, America was a reluctant superpower. Wilson's proudest creation, the League of Nations, was abandoned. The army, massively augmented in 19171918, was demobilised. "There were proposals made to abolish the Marine Corps, and some even wondered about preserving the State Department. The secret office that deciphered foreign codes was closed down. Economically, the nation opted for policies of almost complete self-centeredness, and the share of its national product derived from foreign trade became smaller than ever."3

\footnotetext{
${ }^{2}$ Center for Strategic and International Studies (CSIS), Institute of International Relations and Political Science, Vilnius, Lithuania's Security and Foreign Policy White Paper, 2002, p.1-3.

${ }^{3}$ Kennedy P. "The Next American Century?", World Policy Journal, Spring 1999, Vol.16, Issue 1, p. 53-54
} 
Isolationism harboured a huge potential which was later used during WWII. During WWII, the US possessed both the political will and resources to become a global superpower. According to W.Pfaff, Theodore Roosevelt simply liked war, which he thought, brought out the best in a nation. "Roosevelt would have preferred a war with Germany, bus as he wrote to a friend 'I am not particular, and I'd even take Spain if nothing better is offered". ${ }^{4}$

WWII marked the end of the isolationalist period in US foreign policy. The US became a global superpower, which possessed interests in all corners of the world. Its goal to retain the dominance was later expressed in new formulated doctrines.

After WWII, the USSR established a zone of influence in Eastern Europe and was expanding its influence in different areas. In response, the US created a system of military alliance to counter such expansion. As P.Taylor put it, "If the former USSR is a fortress then the best way to deal with a fortress is to surround it and seal it. In policy jargon this is known as containment, with the ring of post-war anti-Soviet alliances as the seal - NATO in Europe, CENTO in West Asia and SEATO in East Asia". ${ }^{5}$ In 1945, J.Kennan identified three strategic areas that were not to be allowed to fall under the Soviet rule - the United Kingdom, Rein lowlands and islands of Japan. ${ }^{6}$ Indeed, the US clearly defined the geographical limits where Soviet interference would have provoked a military response.

In this two-polar world, the US was seeking domination. According to Ch.Layne, US strategy was not directed solely to the USSR - in this case, after the dissolution of the latter, the US would have withdrawn from Europe. "Having prevailed in the Cold War, the United States could have withdrawn from its costly external commitments. This did not happen, however". ${ }^{7}$ Even during the Cold War, the US was seeking security not through the preservation of the global balance of power, but through domination and hegemony.

The US based its policy upon the determination that security first of all derives from military might in a harsh, competitive world, thus, it is better to be Number One. After the dissolution of the USSR, the US remained engaged in all parts of the world, and its security links with Australia, Taiwan, South Korea, Turkey and other allies continued to be intact. The aspiration to remain a global hegemonic power after the end of the Cold War remained the major element of the global US strategy. Even after the terrorist attacks, the US prefers military solutions to new security challenges it faces today. The US maintains its military presence in all parts of the world and preserves technological lead against possible competitors.

Geographically, Eurasia remains the major object of US foreign policy. According to Z.Brzezinski, Eurasia is the most vibrant and politically active continent on the planet. ${ }^{8}$ Six largest world economies and six biggest defence spenders are located in Eurasia. Only here the competitor to the US global hegemony may emer-

\footnotetext{
${ }^{4}$ Pfaff W. “The Question of Hegemony”, Foreign Affairs, Jan/Feb 2001, Vol.80, Issue 1, p.221233.

5 Taylor P. Political Geography. World Economy, Nation-State And Locality. 3th ed., New York: Wiley, 1993, p.59.

${ }^{6}$ Уткин Б.Н. Американская стратегия для ХХІ века, Москва, Логос, 2000, 13 с.

${ }^{7}$ Layne Ch. "Rethinking American Grand Strategy: Hegemony or Balance of Power in the TwentyFirst Century?", World Policy Journal, Vol. 15, Issue 2, Summer 1998, p.8-28.

${ }^{8}$ Бжезинский 3. Великая шахматная доска. Москва, Международные отношенеия, 2001. p.43-48.
} 
ge. The goal of the US is to preserve the emergence of hostile to the US interests coalition of states.

According to Ch.Layne, "Geographically, the [US strategy] identifies Europe, East Asia, and the Persian Gulf as regions where the United States has vital security interests. Europe and East Asia are important because they are the regions from which new great powers could emerge and where future great power wars could occur. The Persian Gulf is important because of oil." American security guarantees to Europe and East Asia are the essential parts of this strategy. Through these security guarantees, the United States retains the primary responsibility for defending German and Japanese security interests both in the core and in the periphery. Security guarantees give assurance (and provide pretext) for both Japan and Germany not to seek the status of a superpower. Ch.Layne continues: "Washington [always] wanted Western Europe and Japan to be strong enough to help contain the Soviet Union; it did not want them to become strong enough to challenge American leadership". ${ }^{10}$

As Stratfor has put it :"The United States fought World War I, World War II and the Cold War with a single goal in mind: to prevent the unification of Eurasia under any single power. The logic was simple: if any single power could marshal Eurasia's resources, the global balance of power would tilt dramatically against the United States. Therefore, when it became apparent in the two world wars that Germany might well dominate all of Eurasia by itself or in alliance with Japan, the U.S. intervened, albeit at the latest moment possible. During the Cold War, the U.S. intervened from the beginning, having taken away the lesson from World War II that Europe could not maintain its balance of power by itself, and that late intervention by the United States increased the cost to the United States, along with the risk." 11

The last but not least important feature of the US global strategy is to preserve global liberal world economy, which, in G.J.Ikenberry's words is "build order around institutionalized political relations among integrated market democracies, supported by an opening of economies."12 There have always been geopolitical goals of this strategy as well. In US view, "open trade, democracy, and multilateral institutional relations went together. Underlying this strategy was the view that a rule-based international order, especially one in which the United States uses its political weight to derive congenial rules, will most fully protect American interests, conserve its power, and extend its influence."13 The international economic system became an alternative to global power rivalry. This strategy created a vision of cooperation based on common values, traditions and stability, where all participants derive benefits from being part of this system.

In conclusion, in Eurasia, the US executes the strategy of domination using regional balances of power, which overlaps on different levels:

O n

the global scale the US maintains hegemonic policy. Benefits from the participation in the international economic system create interest for independent states to preserve its existence and diminish determination to challenge US

\footnotetext{
${ }^{9}$ Layne (note 7)

${ }^{10}$ Ibidem.

${ }^{11}$ Strategic Forecasting Eurasian Instability and a New American Strategy, Global Intelligence Update, 1110 1999, http://www.stratfor.com

${ }^{12}$ Ikenberry G.J. “America's Imperial Ambition”, Foreign Affairs, Sept/Oct 2002, Vol.81, Issue 5.

${ }^{13}$ Ibidem.
} 
hegemony.

the regional scale, stability in three geostrategically important areas (Europe, East Asia and the Persian Gulf) is maintained by regional balances of power. In these regions, the US fights any attempts to create an anti-American coalition. In Europe, balance of power is assured via preservation of NATO security guarantees to Germany; in Asia - via security guarantees to South Korea, Japan and Taiwan. In the Middle East, the US seeks to prevent the emergence of a leading Muslim state (Iraq, Iran, Saudi Arabia, Egypt, Libya, etc.) able to challenge US interests and rally them into an anti-American coalition.

\section{Strategy after the Cold War - in Search for the National Interest}

Aftermath the Cold War US strategy of domination at the regional level was not translated into concrete national interests and concepts. If earlier external threats, coming from the outside used to determine US foreign policy, later it fell under the growing influence of business, ethnic and other interest groups, thus becoming a derivative of American internal politics.

Samuel P. Huntington argued that "without a sure sense of national identity, Americans have become unable to define their national interests, and as a result subnational commercial interests and transnational and non-national ethnic interests have come to dominate foreign policy." 14 With the disappearance of the Soviet Union, the United States no longer faced a major threat to its security, no major issues were at stake. As General Colin Powell said, when he was the Chairman of the Joint Chiefs of Staff: "I'm running out of demons. I'm running out of enemies. I'm down to Castro and Kim Il Sung." 15

Due to the lack of existential threats, US strategy failed to articulate the main priorities. J.Nye's analysis showed that, for example, "by focusing on certain conflicts and human rights problems, the media pressure politicians to respond to some foreign problems and not others-for example, Somalia rather than southern Sudan in 1992. The so-called CNN effect makes it hard to keep items that might otherwise warrant a lower priority off the top of the public agenda." 16 The policy towards Russia also suffered many changes - though the main principle remained to assure democratisation of Russia and prevent proliferation of weapons of mass destruction - huge resources were put into programmes very distant from these main priorities.

William Perry and Ashton Carter have argued that the way the US understands risks to its security should be rethought. ${ }^{17}$ At the top of their new hierarchy, they put "A list" threats such as the one the Soviet Union once presented during the Cold War. The "B list" features imminent threats to US interests, such as North Korea or Iraq. The "C list" includes important "contingencies that indirectly affect US security but do not directly threaten US interests": "the Kosovos, Bosnias, Soma-

${ }^{14}$ Nye J. "Redefining the National Interest", Foreign Affairs, Jul/Aug 1999, Vol.78, Issue 4, p.22-23.

${ }^{15}$ Waltz K. "The Balance of Power and NATO Expansion", University of California, Berkeley,

Center for German and European Studies, Working Paper 5.66, 1998.

${ }^{16}$ Nye, (note 14), p.24-27.

${ }^{17}$ Ibidem. 
42

lias, Rwandas, and Haitis."

What is striking is how the " $\mathrm{C}$ list" has come to dominate today's foreign policy agenda. Carter and Perry speculate that this is because of the disappearance of "A list" threats since the end of the Cold War. J.Nye argues that "another reason is that "C list" issues dominate media attention in the information age. Dramatic visual portrayals of immediate human conflict and suffering are far easier to convey to the public than "A list" abstractions like the possibility of a "Weimar Russia," the rise of a hegemonic China and the importance of our alliance with Japan." 18

This explains why US policy in the regions where Washington sees no vital interest became unpredictable and was mainly a reflection of internal debates within the American administration. The most important decisions - the first wave of NATO enlargement, the Kyoto Protocol, the ABM Treaty and attitude towards arms control regime fell victims of internal quarrels rather than were an expression of national interest. This had a strong impact on the countries of the CE and Northern Europe region where US policy was inconsistent, whereas support to their aspirations reflected their possibilities to mobilise internal support within the US. One might say that the US administration relaxed in the atmosphere of total rest and tranquillity. External problems seemed to be insignificant echoes of distant events. This lasted until September 11.

\section{Antiterrorism - a New Phase of Domination}

The terrorist attacks in New York and Washington had a profound impact upon the world system. First of all, this strengthened America's determination to dominate - as it had been feared the US did not return to isolationalist policies. Quite the contrary, due to the transnational nature of international terrorism, the political will to shape world politics using vast economic and military resources has received additional impetus.

Using Carter's and Perry's terminology, the emergence of threat "A" consolidated the American political elite. If before foreign policy was a marginal factor in US policy, after the attacks its role became of major importance. The establishment of concrete priorities made US foreign policies more streamlined and predictable.

The antiterrorist campaign was declared priority Number One. As part of this strategy, a successful military campaign in Afghanistan was launched with the potential to be extended to other regions; G.W.Bush named Iran, Iraq and North Korea as countries belonging to "the axis of evil"; for fear of attacks from hostile nations using ballistic missiles, the US withdrew from the Antiballistic Missile Treaty (ABM) and put huge resources into the creation of a missile shield.

US response to the terrorist acts (huge resources and will to act) showed its capacity to simultaneously project power into many distant parts of the world. According to S.Brooks' and W.Wohlforth's calculations, "in the military arena, the United States is poised to spend more on defense in 2003 than the next 15-20 biggest spenders combined. The United States has overwhelming nuclear superiority, the world's dominant air force, the only truly blue-water navy, and a unique capability to project

\footnotetext{
18 Ibidem.
} 
power around the globe. The United States leads the world in exploiting the military applications of advanced communications and information technology and the United States spends three times more than the next six powers combined... And the United States purchases this pre-eminence with only 3.5 percent of its GDP" ${ }^{19}$

Such America's economic dominance, in S.Brooks' and W.Wohlforth's opinion, "surpasses that of any great power in modern history, with the sole exception of its own position after 1945 (when World War II had temporarily laid waste every other major economy)." ${ }^{20}$ In 1999 the US received one third of all world's investments and spent on research and development more than the next seven biggest spenders combined. ${ }^{21}$

Mass culture and democratic values constitute another pillar of American dominance. Without any sense of autoirony, C.Rice in Foreign Policy argued that "American values are universal. People want to say what they think, worship as they wish, and elect those who govern them; the triumph of these values is most assuredly easier when the international balance of power favors those who believe in them. " 22 After the terrorist attacks, Americans attach greater importance to the promulgation and transfer of democratic values around the world.

For the regions of $\mathrm{CE}$ and Northern Europe an increasing importance of values after the September 11 attacks is of primary importance. Until that time, Americans did not pay very much attention to the cultural, religious, lingual cleavages between people. The US was a "large pot", in which these cleavages mixed up and disappeared, and it was hard for Americans to understand why this could not happen somewhere else. Search for terrorists and their clear link with Islamic fundamentalism turned upside down all illusions that had existed before. It is hardly probable that terrorists, by blowing up the skyscrapers where seeking geostrategic objectives. They attacked because their enemies had a different kind of thinking, they had different cultural values and different perception of the world.

Therefore, countries with similar "American values" became even more valuable partners, and the expansion of democracy became an additional front against terrorism. Although being part of US domination, adherence to the principles of democracy together with traditional geopolitical logic becomes an important argument in taking important decisions for Lithuania and its neighbours.

Political, economic, cultural and military domination allows S.Brooks and W.Wohlforth to conclude that "measuring the degree of American dominance in each category begins to place things in perspective. But what truly distinguishes the current international system is American dominance in all of them simultaneously. Previous leading states in the modern era were either great commercial and naval powers or great military powers on land, never both.... Today, in contrast, the United

\footnotetext{
${ }^{19}$ Brooks S., Wohlforth W. "American Primacy in Perspective”, Foreign Affairs, July/August 2002. Vol.81, Iss.4.

${ }^{20}$ Ibidem.

${ }^{21}$ Рогов С. Доктрина Буша и перспективы Российско-Американских отношений. Вашингтон стремится не допустить появления в ХХІ веке равного США по силе противника, Независимое военное обозрение, N.14, 0504 2002, 9 c., http://nvo.ng.ru/concepts/2002-04-05/1_doctrine.html

${ }^{22}$ Rice C. "Promoting the National Interest", Foreign Affairs, Jan/Feb 2000, Vol.79, Issue 1, p.45-62.

${ }^{23}$ Brooks, Wohlforth (note 19).
} 
States has no rival in any critical dimension of power." 23 The US shows no sign of what P.Kennedy in his book Rise and Fall of Great Powers calls imperial overstretch US economy remains quite strong, while investments and military budget are constantly growing.

The unipolar system has taken its final form, and no single state has enough resources to challenge the dominant power. American dominance is so evident, that in C.Rice's opinion "theoretically, the realists would predict that when you have a great power like the United States it would not be long before you had other great powers rising to challenge it or trying to outbalance against it. And I think what you're seeing is that there's at least a predilection this time to productive and cooperative relations with the United States, rather than to try to balance the United States." ${ }^{24}$

US dominance is reflected in new formulated doctrines. For instance, R.Hass, the policy-planning director at the State Department, recently has stated that containment strategy is being replaced by the doctrine of limited sovereignty. "Sovereignty entails obligations. One is not to massacre your own people. Another is not to support terrorism in any way. If a government fails to meet these obligations, then it forfeits some of the normal advantages of sovereignty, including the right to be left alone inside you own country." 25

According to Stratfor Intelligence brief, Defense Secretary D.Rumsfeld gave power to special forces to perform antiterrorist operations on the territory of other countries provided the government of this country refuses to cooperate with the US. This signifies a novel departure in US strategic thinking. "U.S. doctrine since Sept. 11 has been that the United States would strike al Qaeda wherever it was. Ideally the host government would cooperate. If not, the attack would be carried out anyway." 26

Similar actions and doctrines clearly demonstrate the growing dominance of the US, when basic principles of international law are being treated differently according to the newly formulated US foreign policy priorities. In the light of these changes, Washington has enough will and power to implement its national interests, sometimes, even against the opinion of the world community, as it happened with the ABM Treaty, the Kyoto Protocol or the Comprehensive Test Ban Treaty.

\section{Europe in US Grand Strategy}

In US grand strategy, Europe plays the most important role. This reflects both geopolitical and cultural dimension in US foreign policy. The National Security Strategy approved in September 2002 clearly states that "there is little of lasting consequence that the United States can accomplish in the world without the sustained cooperation of its allies and friends in Canada and Europe. Europe is also the seat of two of the strongest and most able international institutions in the world: the North Atlantic Treaty Organization (NATO), which has, since its inception, been the fulcrum of transatlantic and inter-European security, and the European Union (EU), our partner in opening world trade. ${ }^{627}$ Europe is perceived as the hearth of democratic values and a

\footnotetext{
${ }^{24}$ Lemann N. "The Next World Order: The Bush Administration May Have a Brand-new Doctrine", The Newyorker, 01042002.

${ }^{25}$ Ikenberry (note 12 ).

${ }^{26}$ Strategic Forecasting Rumsfeld pushes the Envelope with Forces Proposal, Global Intelligence Update, 1308 2002, http://www.stratfor.com

${ }^{27}$ The National Security Strategy of the United States of America, September 2002, p.25.
} 
major partner in accomplishing mankind's grand project called democratisation.

Europe's status is based on all aspects of the European-American relationship - normative, cultural, economic and military. On the other hand, the status of an ally does not imply that the US wants to see Europe threatening American domination. US vision is a strong and allied Europe, but not strong enough to challenge the US and participate in global power rivalry.

In economic sense, Europe is the biggest US trading partner and investor into US economy. According to the US Census Bureau: Statistical Abstract of the United States, in 2001, European investment made up 69 per cent of all foreign investment in US economy. (Asia - 17, Canada - 8 per cent). A major flow of US investments was also into European economy-52 per cent, Latin America received 29, Asia - 16 and
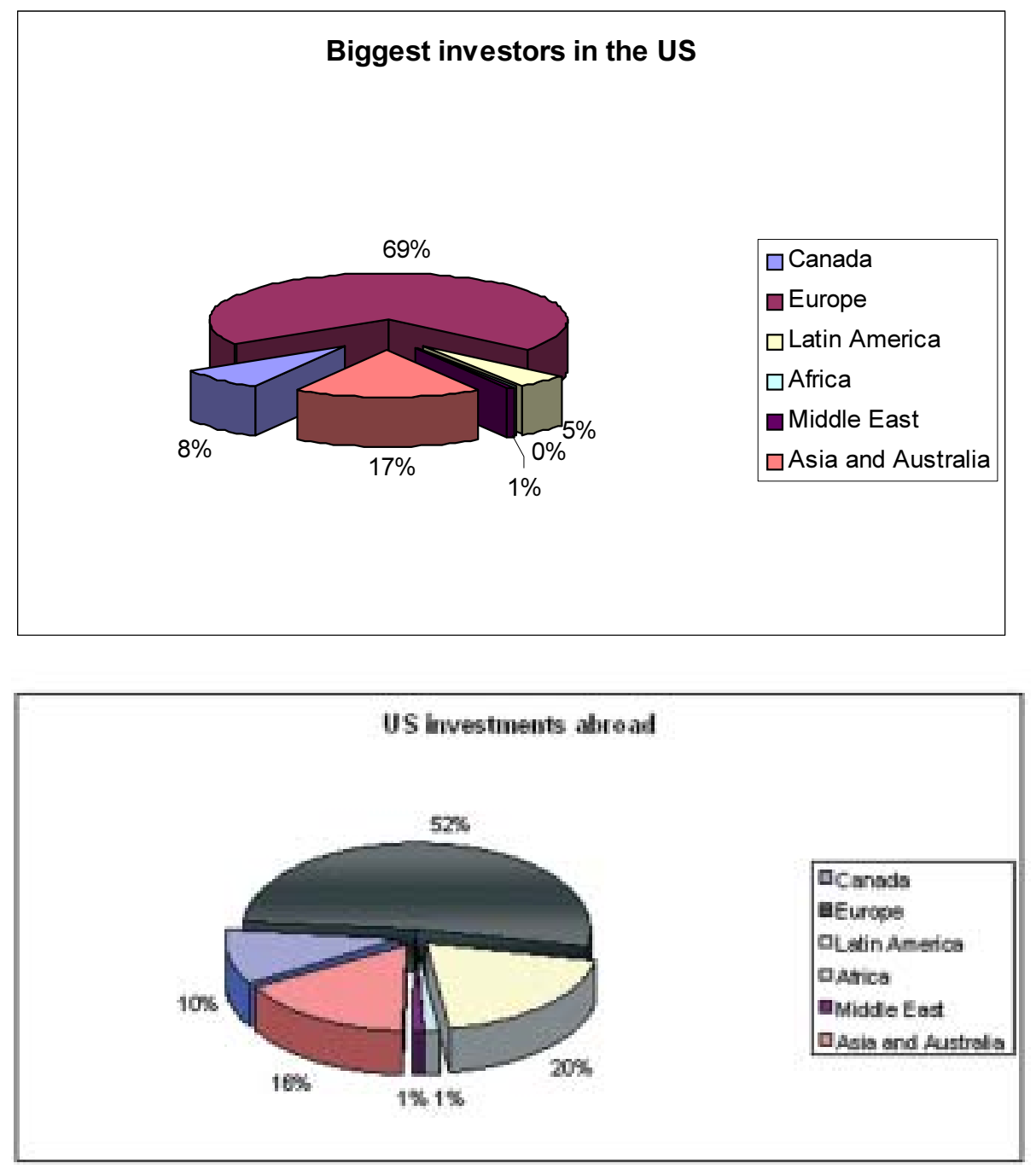

Canada - 10 per cent of American capital. 
2001 Statistical Abstract of the United States / Foreign Trade Division, U.S. Census Bureau, Washington, Source http://www.census.gov/prod/2002pubs/01statab/stat-ab01.html

European countries are the main US trade partners. Even though its dominant position here was downgraded by Canada and Mexico, the European Union still has

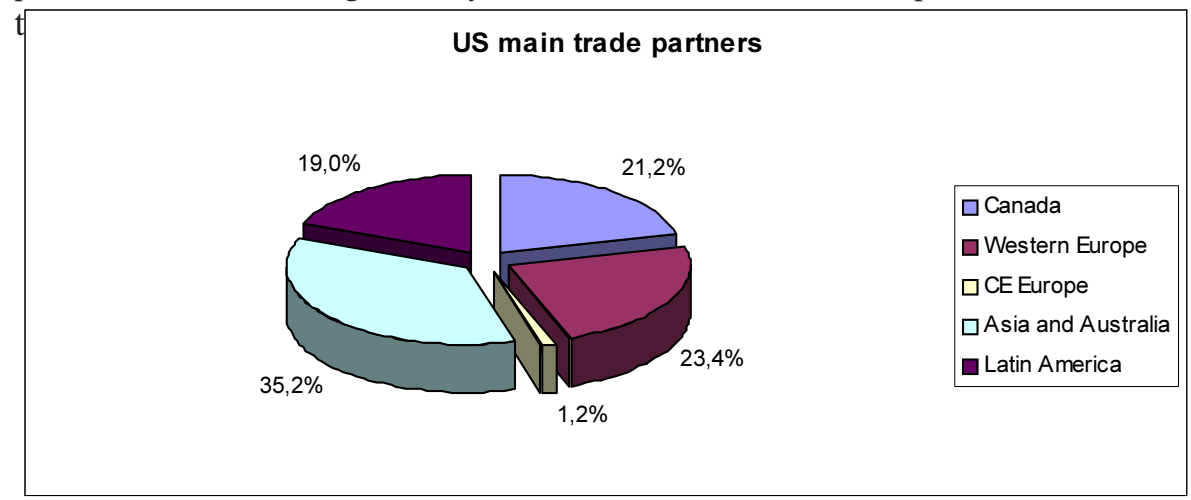

Foreign Trade Division, U.S. Census Bureau, Washington, Source http://www.census.gov/foreigntrade/Press-Release/current_press_release/exh6as.txt

Despite its economic strength, Europe remains, as K. Waltz calls "international-political cipher." ${ }^{28}$ Military structures created in the Cold War era are not suitable to fight modern war and respond to new challenges. European armies need modernisation and reforms. Even quite small EU Rapid Reaction Forces lack some vital capabilities which would enable Europeans fight together with Americans on the same battlefield.

European inability to develop strong and independent military forces preclude Europe from becoming a global superpower and competing with the US. In the future the growing capability gap might even complicate European participation the US-led international military operations. The Kosovo campaign and the operation in Afghanistan and Iraq have already shown that only several European nations could provide forces able to fight together with US forces in high intensity operations.

Due to the capability gap, the US will less and less rely on European contribution in future operations. In his inauguration speech C.Powell stressed that "we believe strongly in NATO. It is the bedrock of our relationship with Europe. It is sacrosanct. Weaken NATO and you weaken Europe, which weakens America" ${ }^{29}$. However in the operation in Afghanistan and Iraq, the United States relied on an ad hoc coalition rather than NATO capabilities.

European military weakness has enormous repercussion for CE and Northern Europe. The weakening transatlantic link and diminishing importance of Europe means a decreasing US interest and lower level of involvement of the US into CE and Northern European affairs. The Center for Strategic and International Studies (CSIS)

\footnotetext{
${ }^{28}$ Waltz (note 15$)$

${ }^{29}$ Testimony of Secretary of State - designed Collin L.Powell Prepared for confirmation hearing of the US Senate Committee on Foreign Relations, 1701 2001, http://www.senate.gov/ foreign/ testimony/wt_powell_011701.txt
} 
and Institute of International Relations and Political Science in Lithuania's Security and Foreign Policy White Paper noticed that "the most unfavorable scenario for Lithuania would be if the U.S. manifestly disregarded the EU and took unilateral decisions on global protection. This could precipitate a rupture in NATO or the impotence of the Alliance, with a lasting impact on the primary security interests of Lithuania." ${ }^{30}$

On the international arena, the US can rely only on the assistance of two states - the UK and France. Only these countries have armed forces that are capable of projecting power far away from their territories. Although the geographical significance of Europe has decreased during the fight against terrorism, in strategic sense its assistance will be needed in later stages. In the operation "Enduring Freedom" in Afghanistan, 8,000 soldiers out of 15,000 were from the US allies. ${ }^{31}$ In fact, it was the contribution of European countries, because only 5 non-European US allies participated in the operation, i.e. Australia, Japan, Jordan, New Zealand and South Korea. Although the US had possibilities to end this operation by itself, it would have faced a real shortage of capabilities without the support from the allies. Even a larger part of contribution from European countries is made in reconstruction works as well as assigning funding for the economy and improving the status of human rights in the country.

In US strategy, NATO plays an important geostrategic role - by providing security guarantees to European countries, the US precludes the formation of a European collective security alliance. The US has no interest in the military dimension of the EU, which could lead to the formation of a single European geopolitical entity able to challenge the US on the global arena. C.Powell has said that "our European allies are in the midst of important efforts to improve their defence capabilities. We will support any such effort as long as it strengthens NATO, not weakens it." ${ }^{32}$ US interest is to preserve NATO as a European security organisation and prevent Europeans from creating a separate EU structure with Americans standing aside.

Inside the EU, the US seeks to prevent the creation of a dominant power able to control vast economic and human resources of the continent and able to speak on behalf of all European nations. The US wishes to speak to each country individually and not to a block of countries. Therefore, further EU centralisation and integration are not in accordance with US view of the world. The United Europe with a sophisticated structure and quasi-government would imply that the EU has turned if not into a strategic enemy, then, at least into a strategic competitor able to disrupt the unipolar world order. According to the same logic, the US is not interested in the Russia-EU rapprochement. Such alliance would unite their economic and military resources and potentially could have a huge impact on the global balance of power.

To summarise, in its global strategy the US expects from Europe not competition but support and approval. The European centre of global power or local European hegemon is an American geostrategic nightmare. Such attitude towards Europe

\footnotetext{
${ }^{30}$ Center for Strategic and International Studies (CSIS), Institute of International Relations and Political Science, Vilnius, (note 2), p.53.

${ }^{31}$ US Department of Defense International Contributions to the War Against Terrorism, Fact Sheet, revised 1406 2002, http://www.defenselink.mil/news/Jun2002/d20020607contributions.pdf

${ }^{32}$ Testimony of Secretary of State C.Powell (note 29).
} 
48

dictates US view and policy towards CE and Northern Europe. Regional Approach - CE and Northern Europe in US Global Strategy

Europe has a very specific place in American strategy, every country that has influence on the balance of power on the continent and participates in the decisionmaking process, becomes an important part of US policy. The most important partners of the US are the UK, Germany, France, but, inside the EU, small states also have a disproportionally large degree of influence. This is particularly true speaking about the Nordic states. Therefore, the policy of the US regarding old and new members will be based upon their future influence and activeness in Europe.

Because of their limited resources and capabilities, Lithuania and its neighbours are viewed from US perspective as part of one or another region. With the importance of CE Europe increasing, chances of Lithuania to get more attention in Washington can receive additional boost.

Specifically, the policy of the US towards CE and Northern European regions is part of a broader policy of the US towards Europe, in which the US seeks:

to get

support of the countries in fight against terrorism and proliferation of weapons of mass destruction (political, economic, military support); to as-

sure development of democratic societies throughout the world and in Eurasia, including Russia, Byelorussia, the Ukraine, the Caucasus, the Balkans;

to su-

stain prevalence in Europe (to strengthen the transatlantic link, preserve the balance of power in Europe, prevent militarisation of the EU, fix borders of Russia);

- .................................................................................................................. $\mathrm{t}$

maintain economic ties with the EU, to guarantee flows of investment, to expand the market for defence industry production.

US policy towards CE and Northern Europe is constructed in accordance with these general interests. This is true to both $\mathrm{CE}$ and Northern Europe. Because of specific features, every country in the region has a special role and tasks in US strategy, and this list shows very clearly what the US expects from Lithuania and its neighbours. On the other hand, the countries of the region have their own opinion on what role the US has to play in Europe.

Although the CE and Northern European regions are different in their economic, social, cultural characteristics, due to their specific location, the policy of the US towards them has many similarities. The main factor that unites them is the proAmerican orientation, which is influenced mainly by the fact that the countries, in the sense of security, are dependent on the US and do not imagine the European security architecture without American involvement.

In Europe both CE and Northern European countries and the US seek to prevent the emergence of a dominant power-be it Germany, Russia or France. This is especially true in CEEurope, which historically was battlefield between Germany and Russia, between the West and the East. Not surprisingly, "Pechenegs, Tatars, Turks, Muscovites and

\footnotetext{
${ }^{33}$ Liebich A. East Central Europe: The Unbearable Tightness of Being, Yale University, Historical
} Roots of Contemporary and Regional Issues, Occasional Paper Series, No.15, 1998. 


\section{Pro-American Europe}

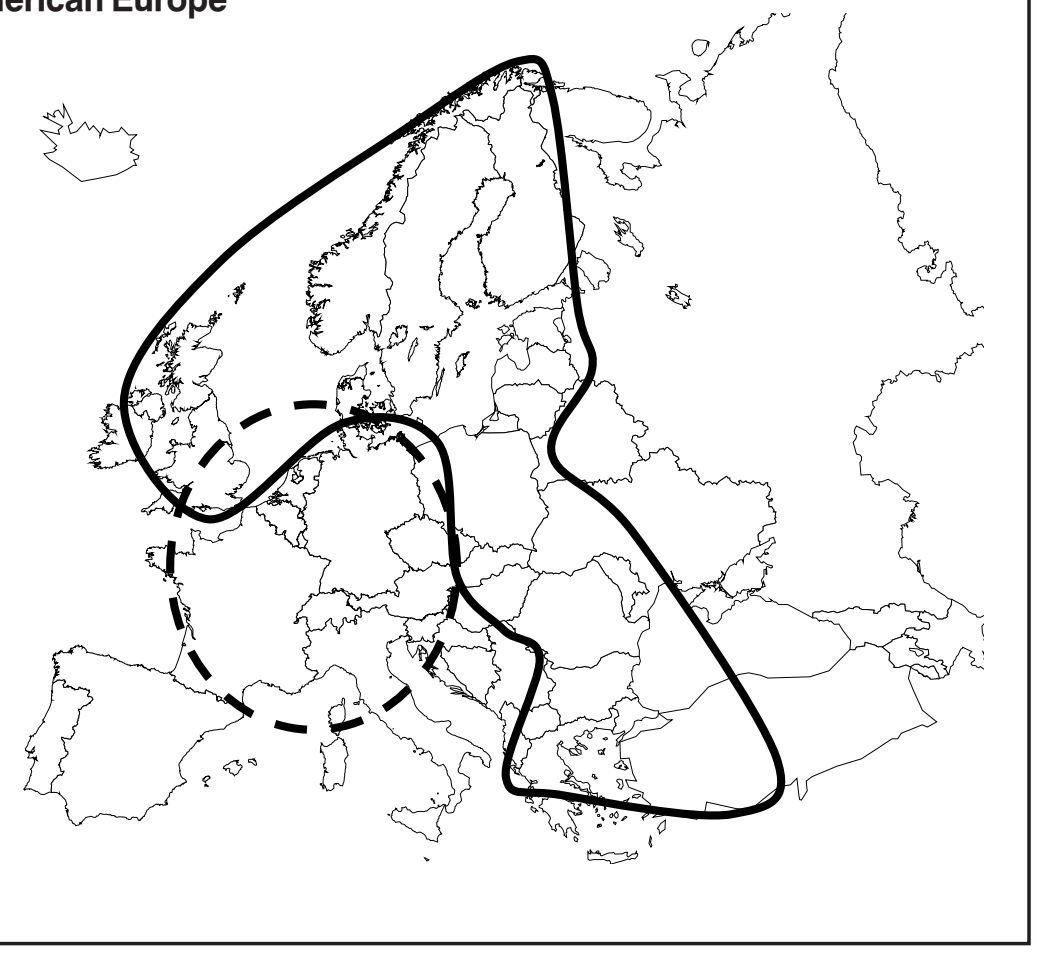

Soviets, all merge into one continuum where they mingle with Teutonic knights, Prussians and Hitlerites". A.Liebich continues, "German historians have referred to Zwischeneuropa, intellectuals and politicians have translated "middle" into "centre" and have spun an ideology of "Central Europe'. However, being "in the middle" is hardly the same as being "at the centre."The centre imposes itself upon history whereas the middle is subjected to it." 33

Due to the complicated geostrategic situation of being squeezed between two huge neighbours, CE Europeans have developed very specific attitudes towards their neighbours. They loathe the Russians, are suspicious of other Europeans and are attracted to the Americans. For them it is true today what was true for many West Europeans fifty years ago: to keep the Russians out, the Americans in and the Germans down. For them NATO enlargement means that in the region which was the subject of a fierce Russian-German geopolitical competition, CE European countries will feel strong American involvement. Without Americans, the region may again become a geopolitical battlefield arena.

North European countries are driven by similar geostrategic motives. During the Cold War, a subtle Nordic balance existed in the region. This balance was based upon American security guarantees to Norway and Denmark and its ability to counter Russian influence in other countries. After the twelve years since the end of the Cold War, Northern Europeans still need American involvement that allows them to feel more comfortable not only with Russians, but also with others aspiring to become great powers on the European continent.

The second important feature of the US - CE and Northern European rela- 
tionship is the asymmetry of power between them. The US speaks to the region from the position of the strong. CE and Northern European countries possess no capabilities that would make the US feel dependant upon them. The antiterrorist campaign provides a good example - the US values the input of all countries, but their refusal to participate would not harm the operation in any way. The region would grow stronger if its countries created certain specific capabilities that the US does not possess or feels urgent shortage. Such capabilities could be intelligence information, experience of working with certain regions, specialised military units, high-tech equipment, etc.

The importance of CE and Northern Europe increased during the antiterrorist campaign. If earlier the region was perceived mainly as a tool to contain Russia, now, when the US got involved in the war against terrorism, the region obtained a new status. From a zone of confrontation CE and Northern Europe became a tool to promote American values and interests.

Geographically, Lithuania and its neighbours are distant from "hot spots", and the US, except for flights through the zone of those countries, does not need their territories for the deployment of armed forces. Trouble spots and camps of terrorists were not found in the region. There are no weapons of mass destruction here, and it does not pose any real danger of proliferation. Financial resources of terrorists were also deposited elsewhere, not in the banks of CE and Northern European countries, economic ties with Arab countries were not very close. Geographically, the Middle East and the Gulf region are becoming prioritised regions for the US, countries of Central and Southern Asia are assuming a new role (Uzbekistan, Tajikistan, Afghanistan, Pakistan, Kirghisia).

The geographical distance from the zones of conflicts and tensions means that in the strategy of the US, the role of CE and Northern Europe has dramatically changed. If until now the US paid a lot of attention to the stabilisation of our region, now the US anticipates support for the implementation of its global tasks. From a consumer of security our region is gradually becoming a supplier of security. Further attention of the US to our region will largely depend on the activity and resources of the countries of the region in exporting security to other countries and thus contributing to the implementation of US policy.

\section{Promotion of Democratic Values}

The American model of globalisation rests upon the assumption that democratic states that share similar values do not fight each other, and free trade leads to prosperity for all nations. On September 11, terrorists challenged the world, where free trade, human rights and democracy prosper. The attacks did not lead to the demise of democracy - they even more consolidated democratic nations.

J.Kurth in his article "The next NATO: Building an American Commonwealth of Nations" noticed that the regions where the American way of globalisation is succeeding are actually rather few, and together they constitute much less than half the area of the globe and much less than half its population. "These regions include almost all of Europe, much of Latin America, some of the countries of the periphery

\footnotetext{
${ }^{34}$ Kurth J. "The Next NATO: Building an American Commonwealth of Nations" The National Interest, Fall 2001, http://www.expandnato.org/kurthnato.html
} 
of East Asia, and of course Australia and New Zealand. As it happens, these four regions largely correspond to the US system of alliances as it existed fifty years ago (NATO, the OAS, a series of bilateral treaties with Asian countries, the ANZUS). The extent of "globalization" in 2001 is not that different from the extent of the "Free World" in 1951." ${ }^{4}$

Here, only one big difference exists - the countries of CE Europe that are successfully becoming part of the liberal-democratic and free-market Europe. CE Europe is the region round which the two rounds of NATO expansion occurred. It is this difference that links the American way of globalisation with the American proposals for NATO enlargement.

J.Kurth continues that "today, ten years after their heroic restoration of their national independence, the Baltics have been extraordinarily successful in establishing and embodying the American values of liberal democracy, the free market and the rule of law." ${ }^{35}$ US politicians frequently stress that democracy is the ultimate measure against terrorism. By offering moral and practical support after the terrorist attacks Lithuania, along other European nations, psychologically and in real terms became valuable allies to America and its people.

Even more, the new CE European democracies started to transfer democracy to other regions. Their specific area of expertise and the knowledge of their eastern neighbours can provide a significant contribution to the extension of liberal-democratic values to the Ukraine, Belarus, countries of the Caucasus or Central Asia.

The Nordic countries are already enjoying the privileged status in Washington and European capitals due to their active involvement in other regions. In early 90s, the Nordic countries devoted huge resources to Lithuanian, Latvian and Estonian economic development, structural reforms and Euro-Atlantic integration. Their active policy and support to the countries in transition made the Nordics very valuable partners for all countries in CE Europe.

Until now, Washington has strongly believed in democracy in Russia. The first wave of NATO enlargement was strongly related to the fear that the admission of the Baltic states would strengthen nationalism in Russia, thus putting democracy in Russia under risk. Now the US has less illusions about democracy in Russia, especially if one compares its progress to the achievements of CE European countries.

Today, only Belarus remains a black hole in the process of turning Europe into a fully democratic continent. Therefore, in the future Poland and Lithuania will have to play a significant role in strengthening American and European efforts to democratise this country.

Efforts to expand the zone of democratic values in Europe and beyond its boundaries will further remain a factor that unites interests of America and the countries of $\mathrm{CE}$ and Northern Europe. This is a golden opportunity for CE and Northern Europeans to contribute significantly to American strategic goals that coincide with the European interest to strengthen security and democracy in the eastern part of the continent.

\section{Assistance in Fighting against Terrorism and Keeping Peace in the World}

${ }^{35}$ Ibidem. 
The terrorist acts once again showed the politicians of the US the importance of military means in guaranteeing state security and prosecuting criminals. Now, those allies, who can practically - by military capabilities, financial or intelligence resources - contribute to military operations have the biggest advantage. The ability to contribute becomes one of the keys to the membership in NATO.

The creation of modern and effective military forces is the most important recommendation that the US gives to NATO countries and candidates. The US renders a large part of support to the countries of the region, and if we excluded three countries that receive the largest part of US assistance - Israel, Egypt and Jordan CE Europe would appear as the most significant receiver of US military assistance. It reflects the interest of the American administration to see countries that can practically contribute to US military operations.

The US values the assistance from partners and capabilities provided during the operation in Afghanistan (air space, airports, special forces, economic measures). NATO candidates are especially encouraged to create units, interoperable with NATO forces. This means that the potential for them to participate in common military operations is increasing. Especially important is the contribution of partners to peace support operations. All countries that are seeking membership in NATO have deployed decent-sized capabilities in the Balkans, other countries additionally have forces in other parts of the world. This allows the US to redeploy its military and to use them in other operations.

Therefore, even though the region does not have the capabilities that could influence the world's military balance, the active participation of CE and Northern European countries in the antiterrorist campaign and peace support operations contributes to the stability in other parts of the world. Although here our region is not an independent actor, it is valuable as a promoter of the global strategy of the US.

\section{Geostrategic Balance in Europe}

From the American perspective, the importance of CE and Northern Europe mainly derives from its ability to influence European politics, or, more precisely, decision-making in the EU that might have an impact on the global balance of power. America shares with CE and Northern European countries common security interests, such as to keep the transatlantic link, democratise Russia, preserve NATO's role, avoid centralisation and militarisation of the EU.

Together with the United Kingdom, CE and Northern Europeans constitute the pro-American part of Europe sharing similar threat assumptions and still considering military means as a prerequisite for national security. The Institute for Foreign Policy Analysis (IFPA) in the study Strategic and Operational Implications of NATO Enlargement in the Baltic Region, has put that "Estonia, Latvia, and Lithuania could constitute part of a core of Eastern and Central European states that serve as "new Atlanticists," states who have a compelling interest in keeping the United States involved in European security, who seek to ensure that collective defense remains the Alliance's raison d'être". ${ }^{36}$ These countries resist NATO's "watering down" into an

\footnotetext{
${ }^{36}$ Institute for Foreign Policy Analysis (IFPA) Strategic and Operational Implications of NATO Enlargement in the Baltic Region, 2002. - p.1
} 
OSCE-type organization or outright replacement by an EU defence capability.

The countries that share a common border with Russia or Belarus are extremely cautious about EU ability to guarantee security and are looking for American security guarantees. The US also understands that countries, such as Lithuania, that has a common border with the militarised Kaliningrad district, even after the membership in the EU, first of all will ally its security policy with that of the US. Such security dependence will allow the US via CE and Northern European countries exert more influence upon EU decisions, especially those related to European Security and Defence Policy (ESDP). Denmark, which is not fully participating in ESDP and did not become a member of the WEU, already for several decades has been playing a similar role.

Similar geostrategic objectives within Europe and beyond it make CE and Northern countries closer US allies than Germany or France. Therefore, NATO's eastward enlargement preserves and in the future will strengthen US influence in the EU even more. Kenneth N. Waltz in his article The Balance of Power and NATO Expansion emphasised "The Bush administration saw, and the Clinton administration continues to see, NATO as the instrument for maintaining America's domination of the foreign and military policies of European states." ${ }^{37}$ The successful conclusion of the EU membership negotiations made NATO enlargement a priority in the G.W.Bush administration.

American security guarantees to CE Europeans is part of American strategy to preserve the transatlantic link and avoid duplications of European capabilities separate from NATO. After a successful integration into NATO these countries will give priority to strengthening NATO rather than deepening the EU military dimension. The Nordic countries also object the EU's militarisation - they prefer a civilian element of European Union crises management efforts and object to the creation of a new European military machine. Their policy coincides with the American interest and will find support in Washington.

CE Europeans escaped from the Soviet domination just ten years ago and they are unlikely to easily give up their hard-won sovereignty to central authorities in Brussels. After becoming members of the EU, these countries will slow down the further European integration, especially in the military field. Their policy will coincide with the American interest to talk to Europeans separately, not as a group of countries. Washington seeks to keep a fragmented Europe that does not compete with America in world affairs. Not surprisingly, the European Commission demanded from candidate countries to accede to the whole European Union acquis without any exceptions that Denmark and the United Kingdom, for instance, had negotiated previously. ${ }^{38}$

NATO enlargement and security guarantees to CE Europeans solve another US foreign policy objective - to prevent the formation of the Moscow-Berlin axis.

\footnotetext{
${ }^{37}$ Waltz (note 15).

${ }^{38}$ For instance, only when Denmark received four exceptions from the Maastricht Treaty, it managed to ratify it. The European Documentation Centre (EDC) at the University of Mannheim Protocol On Denmark The High Contracting Parties, Desiring To Settle Certain Particular Problems Relating To Denmark, http://www.uni-mannheim.de/users/ddz/edz/doku/vertrag/engl/m_proto.htm ${ }^{39} \mathrm{У}_{\text {ткин (note 6) }}$
} 
A.Utkin has pointed out that "instead of becoming a transparent corridor between the East and the West, the Baltic states, together with Poland, the undecided Ukraine and Moldova, became a wedge between America, Europe and Russia. Their integration into transtatlantic structures turned them into a zone of intense geopolitical tension between Moscow and Washington". ${ }^{39}$

During the antiterrorist campaign, debates over NATO enlargement ceased to be a confrontational issue between Washington and Moscow. Both Russia and America were fighting terrorists in different parts of the world. The Baltic states and their neighbours lost their confrontational status and became an integral part of a free and democratic Europe. The US also understands that NATO enlargement into the Baltic states will force Sweden and Finland to rethink their security policy and these countries might one day join the Alliance. Such move would completely change the European security architecture and consolidate Europe under American leadership.

G.Gorenburg has pointed out that "if the Baltic States' accession to NATO proceeds smoothly, it is likely that Finland and Sweden will seek to join NATO as well within the next 5 years. These two states would contribute significantly to NATO military capabilities both in and out of area. Their admission would turn the Baltic Sea almost completely into a NATO lake. This could lead to the establishment of a real security community in the region, where cooperation among NATO and EU members would flourish, where Russia would not be threatened, where Lithuania, Latvia, and Estonia could rejoin the West, and where allied militaries could work together in a very useful environment." 40

Inside the EU the pro-American CE and Northern Europe (especially if we take the British Isles as part of the region) will outbalance other centres of powerGermany or France. The economically developed Northern European region in the nearest future could become a solid competitor to Germany - the strongest EU economy. Small but highly developed Nordic countries together with the Baltic states in the European Council will control 39 votes (approximately 12 per cent). Together with Poland and the United Kingdom, the region will control 95 votes, which means veto right in the European Council. ${ }^{41}$

CE European countries will enjoy a similar degree of influence within the EU. After the first wave of EU enlargement, CE Europeans will control 77 votes ( 8 votes missing to reach the blocking minority). Provided Romania and Bulgaria join in 2007 , the region's voting power will increase to 101 votes (veto right).

After the membership in the EU, both CE and Northern European countries will enjoy a higher degree of influence and power. In addition, by coordinating their efforts, these countries may even more successfully pursue their security policy agenda that will allow them to increase their weight in the eyes of decision-makers in Washington.

\section{Economic Cooperation}

The economic dependence of the United States on CE and Northern Europe-

\footnotetext{
${ }^{40}$ Gorenburg D., etc. The Expansion of NATO into the Baltic Sea Region: Prague 2002 and Beyond. CNA Corp., Centre for Strategic Studies, 2002, p.2

41 "Treaty of Nice" Official Journal of the European Communities, 103 2001, p.C 80/1.
} 
an markets is relatively small. Northern European countries account for slightly less

\begin{tabular}{|c|c|c|c|c|c|c|c|c|}
\hline & 1993 & 1994 & 1995 & 1996 & 1997 & 1998 & 1999 & 2000 \\
\hline $\begin{array}{l}\text { N5 (Nordic } \\
\text { countries) }\end{array}$ & 1,60 & 1,53 & 1,59 & 1,68 & 1,69 & 1,54 & 1,63 & 1,63 \\
\hline B3 (Baltic states) & 0,02 & 0,03 & 0,03 & 0,03 & 0,04 & 0,04 & 0,05 & 0,08 \\
\hline CE Europe & 0,25 & 0,27 & 0,26 & 0,26 & 0,30 & 0,34 & 0,37 & 0,42 \\
\hline NB8 (N5+B3) & 1,62 & 1,55 & 1,62 & 1,72 & 1,73 & 1,58 & 1,68 & 1,71 \\
\hline N5 + CEE & 1,85 & 1,80 & 1,85 & 1,94 & 1,99 & 1,88 & 2,00 & 2,05 \\
\hline
\end{tabular}

than 2 per cent, CE Europe -0.42 per cent of the overall US foreign trade. Even though trade flows are constantly increasing, in the foreseeable future both regions will not become strategic markets from the US point of view.

\section{US Foreign trade statistics}

U.S. Census Bureau, Statistical Abstract of the United States, 2001.- p.802-805.

The defence industry sector may become a special area of cooperation. As the technological gap between America and Europe is widening, technological transfer

\begin{tabular}{|crrrr|}
\hline & \multicolumn{5}{c|}{ Defence expenditures } \\
\cline { 2 - 5 } State & \multicolumn{5}{c}{ (mln. USD) } \\
& 1997 & 1998 & 1999 & 2000 \\
Czech R. & 987 & 1.132 & 1.155 & 1.133 \\
Hungary & 666 & 647 & 768 & 777 \\
Slovakia & 414 & 407 & 305 & 340 \\
Slovenia & 329 & 360 & 337 & 223 \\
Poland & 3.073 & 3.356 & 3.222 & 3.191 \\
Lithuania & 135 & 134 & 107 & 195 \\
Latvia & 156 & 157 & 58 & 70 \\
Estonia & 65 & 68 & 71 & 79 \\
Bulgaria & 339 & 390 & 392 & 347 \\
Romania & 793 & 870 & 607 & 809 \\
Albania & 94 & 98 & 140 & 111 \\
Macedonia & 132 & 136 & 67 & 76 \\
& 9180 & 9753 & 9228 & 9351 \\
\hline
\end{tabular}

may become one of important tools to close this gap and prepare the new allies to fight alongside Americans. NATO has always emphasised that an applicant must create modern and effective armed forces. This means to spend more on defence and procure modern weapon systems. Not surprisingly, defence budgets in CE European countries are rapidly growing, in 2000 they reached $9.3 \mathrm{bn}$. USD and will continue to grow.

Wilk A. The new members of the new NATO // http://www.osw.waw.pl/en/epub/eRap2002/ecz_01.htm, 
NATO membership aspirations so far have not resulted in acquisitions from US companies. With the exception of Poland new NATO members, the Czech Republic and Hungary, are still discussing the big acquisition projects. Both America and European countries exercise political arguments to influence decisions that will be made in Prague and Warsaw.

Lithuanian has so far maintained a leading role in acquiring US technological products. It started with tactical radios from Harris Corp., later turned its attention to Javelin antitank systems from Lockheed Martin ir Reytheon Corp., and Stinger antiaircraft systems from "Hughes Missile System Company" and "General Dynamics / Raytheon Corp." ${ }^{42}$

\section{Lithuania and other Baltic States in US Global Security Strategy}

Common understanding of security, common values and common threat perception is the uniting factor between the US and countries of CE and Northern Europe. However, their economic inter-dependency and trade flows are not high. Those factors dictate the agenda for US policy in the region, where themes of regional stability, NATO enlargement, relations with Russia dominate versus economic themes.

US policy towards Lithuania reflects a broader US security and foreign strategy, where promotion of regional security, fight against terrorism, fostering of foreign investment, economic reforms and free trade, fight against criminality and corruption play a very important role.

The US pays special attention to internal policy aspects, such as the issues of genocide, return of property to the Jews, democratisation and privatisation, attitude towards ethnic minorities, etc. In external relations, it is important for the US that Lithuania can strengthen the US - Europe relations, contribute to fight against terrorism, participate in NATO missions, improve relationships with Russia or contribute to the development of democracy.

From the geopolitical perspective, Lithuania and the other countries of the region are not pivot areas in the grand strategy of the US. They do not play a vital role in fight against terrorism, there are no strategic resources on their territories (oil, gas, nickel, etc.), there are no important communication lines, geographically they do not control important channels or entrances to strategically important regions, and the size of their trade is a small part of the whole US foreign trade.

Even so, this quiet and relatively rich part of the world has certain features that

\footnotetext{
${ }^{42}$ BNS [Lithuanian Armed Forces will be armed with Stinger systems] Lietuvos kariuomene bus apginkluota "Stinger" raketomis 2002 spalio $11 \mathrm{~d}$.
} 


\begin{tabular}{|lccc|}
\hline & CE Europe & $\begin{array}{c}\text { Northern } \\
\text { Europe }\end{array}$ & Baltic states \\
\hline $\begin{array}{l}\text { Normative dimension } \\
\text { democratisation of Eastern }\end{array}$ & + & + & + \\
$\quad \begin{array}{l}\text { Europe } \\
\text { promote democratic values in } \\
\quad \text { other regions }\end{array}$ & $+/-$ & + & $+/-$ \\
$\begin{array}{l}\text { Capabilities } \\
\text { power projection }\end{array}$ & & & - \\
$\quad \begin{array}{l}\text { antiterrorism } \\
\text { crisis response operations }\end{array}$ & + & $-/+$ & +- \\
$\begin{array}{l}\text { Strategic balance } \\
\text { preserve transatlantic link } \\
\text { prevent EU militarisation }\end{array}$ & + & $+/-$ & + \\
$\quad \begin{array}{l}\text { Ealance Germany inside the } \\
\quad \text { EU }\end{array}$ & + & + & + \\
$\quad$ integration & - & + & +- \\
$\quad$ prevent Russian expansionism & + & + & + \\
$\begin{array}{l}\text { Economic relations } \\
\text { trade } \\
\text { defence industry }\end{array}$ & + & + & - \\
\hline
\end{tabular}

are important to the implementation of US strategy, especially American interests in Europe, i.e. that are mostly of regional, not global level. Europe will stay the major object of US foreign policy, therefore, Lithuania and countries of this region will have the largest importance in common European context.

The table shows the spheres, where Americans expect CE and Northern European countries can find areas for cooperation:

In order to preserve active American interest in their security, Lithuania and other Baltic states must find areas where their efforts would make a difference for the US. Several aspects are of particular importance:

future member of the EU, Lithuania together with other neighbours will influence EU decisions. The bigger influence these countries will have in Brussels, the higher degree in influence they will enjoy in Washington;

huania together with other countries may act as a force multiplier of US efforts to promote democracy and fight terrorism.

\section{Costs and Benefits of US Involvement}

US involvement into CE and Northern Europe is closely linked with the anticipated costs and benefits of its activities. Lithuania has a vital interest to keep American attention to the $\mathrm{CE}$ and Northern European region, therefore, its efforts must be directed at creating favourable economic, political or military conditions for cooperation.

Lithuania's interest to have the US in Lithuania derives from its geostrategic realities. During the last century, Lithuania's chances to preserve its statehood were dependant upon Russian expansionism. Historical experience made Lithuanians very sensitive to changes in Russian politics. After the Cold War Russia lost the status 
of a great power - this change allowed Lithuania to strengthen its independence and integrate into the transatlantic community. Imperialist ambitions of Moscow have not declined - only the lack of resources does not allow Russia to continue its traditional policy of keeping the eastern coast of the Baltic Sea at its disposal.

The membership in NATO and the EU means that for an unlimited period of time the Baltic states are withdrawn from Moscow's expansionist plans. On the other hand, the membership does not automatically imply that these countries have completely escaped from the Russian orbit. Russia will maintain its influence primarily by using economic measures and Lithuania's dependence upon Russian gas and oil. Provided the Russian-EU cooperation in the energy sector develops into a strategic partnership, Moscow will acquire an additional level in the region.

Russia maintains its interests in the Baltic states, but the means it uses are mainly economic. Economic sanctions or blackmail would be extremely painful to Lithuania and its Baltic neighbours. EU membership provides certain guarantees against similar measures, but does not solve Lithuania's geostrategic dilemma of being between two - European and Russian - centres of power. Lithuania needs the third geostrategic vector that would compensate the tension that derives from the existence of the two competing centres of gravity. US presence introduces the third vector into the Baltic geostrategic equation and provides flexibility for Lithuania to balance different influences and interests.

The US also has interest in preserving stability in the region which plays an important role in the European balance of power. The Institute for Foreign Policy Analysis admitted that "NATO membership cannot inhibit Russian manipulations of energy supplies or efforts to 'play the ethnic card', but the support of the Alliance and the backing of its security guarantee can embolden the Balts to handle Russia's baiting and coercion more effectively." 43 NATO enlargement provides a clear indication for Russia that Cold War borders are no more valid in Europe, and in the New World Order the US plays the most important role.

A more robust American commitment to the Baltic states, which used to be a zone of geostrategic tension, means not only additional benefits but also costs for the US administration. Security guarantees are a consequence of a long-lasting American commitment to the region. L.Wallin recalls that "in the mid-90s, there were suggestions, e.g. from British and German officials, that Sweden and Finland should assume the responsibility for their security, but the proposed protectors were neither capable nor willing to take on such a role. In the US, there was a growing awareness that a Baltic 'grey area' could have negative implications for overall European stability and security". ${ }^{44}$ American concern was most clearly expressed in the RAND

\footnotetext{
${ }^{43}$ Institute for Foreign Policy Analysis (note 36), p.2.

${ }^{44}$ Wallin L. NATO Enlargement in the Baltic Sea Area - Possible Consequences for Sweden, The TESLA Group, Swedish Defence Research Agency, 2002.

${ }^{45}$ Asmus R., Nurick R. "NATO Enlargement and the Baltic States", Survival, Vol.38, N 2, 1996, p. 121-142.

${ }^{46}$ Charter of Partnership Among The United States of America and the Republic of Estonia, Republic of Latvia, and Republic of Lithuania. http://www.usemb.ee/charter1.php3 , accessed 29 102002.
} 
study "NATO Enlargement and the Baltic states" published in $1996 .{ }^{45}$ The analysis and recommendations of this study argued for a more active American policy for the Baltic Sea area in the second half of the 1990s. One outcome of this was the Baltic Charter, concluded between the US and the three Baltic states in January 1998. The Charter proclaimed "real, profound and enduring" American interest to the Baltic states. ${ }^{46}$ In exchange for a greater near-time American political and military engagement and explicit promises of eventual NATO membership, the Baltic states agreed to wait for a later round of enlargement.

Several reasons contributed to the lack of commitment to the Baltic states in 1996. First of all, their membership was not considered as a vital element for the security of Western Europe. R.Asmus and R.Nurick have pointed out "what the Baltic states most lack is the active support of the strongest European powers in the Alliance - Germany, France and the United Kingdom. When many NATO members ask themselves whether the Alliance would and should be willing to go to war to defend the Baltic states against foreign aggression, the answer is often muted and unclear, and sometimes simply negative." ${ }^{47}$ Most American decision-makers were convinced that "the United States has no significant strategic or economic interests in these [Baltic] countries, and certainly none that are anywhere near as weighty as the very substantial strategic assets risks and costs that would come with a US commitment to them". ${ }^{48}$

Even at the beginning of 2001, most Western analysts were convinced that Lithuania will not be invited during the second round of NATO enlargement. For example, on 30 April 2002 an influential think-tank Stratfor published analysis called "Baltic States membership in NATO unlikely". Stratfor argued that the military situation in the region prevents NATO from moving into the Baltics: "Defending and reinforcing the region is difficult because of the region's broad front, limited depth and restricted lines of communication. In the event of war, the Baltic states would need to be reinforced, as Russian forces would neutralize the Baltic states in their move to protect Kaliningrad and its port facilities. NATO would need to move reinforcements overland, because Kaliningrad would make air and sea resupply difficult. The road networks, developed over years of Soviet rule, favor Moscow. Limited ability to reinforce the region would allow Russia to secure the Baltic states, leaving a large number of NATO troops waiting on the beach for rescue." 49

Contrary to Stratfor's forecast in November 2002, NATO decided to invite Lithuania and its neighbours to join the Alliance. "Suddenly" it appeared that Americans were ready to sacrifice part of their resources in providing security guarantees to earlier thought undefendable nations. This historical turn reflects decreasing costs and increasing interest and benefits of American involvement into the Baltic region.

Especially after the September 11 terrorist attacks, the US pays more attention to the countries that share the same values and belief and are ready to stand beside America in fighting terrorism and promoting democracy. J.Kurth has pointed out that in a very short time the Baltics have successfully established liberal democracy, the free

\footnotetext{
${ }^{47}$ Asmus, Nurick (note 45), p. 124.

${ }^{48}$ Kurth (note 34)

${ }^{49}$ Strategic Forecasting Baltic States Membership in NATO Unlikely, Global Intelligence Update,

2704 2001, http://www.stratfor.com

${ }^{50}$ Kurth (note 34).
} 
market and the rule of law. "If any countries ever deserved to become members of NATO by virtue of their achievements by American standards, these do." 50

In addition, growing economy accompanied by successful negotiations over EU membership hinted that the Baltic states, along with the whole pro-American CE and Northern European region, could be utilised in accomplishing US interests. If earlier the American policy towards the Baltic states was directed by arguments of rebuilding historical truth, from late nineties the US has also been seeking clear geostrategic objectives and benefits.

Strategic partnership between the US and Russia, growing Baltic military expenditures and increasing military capabilities, EU membership mean lower costs of US involvement in the region. New NATO-Russia relations significantly decreased the fear of confrontation with Russia over the next wave of NATO enlargement.

Making full use of favourable circumstances, the US decided to consolidate its domination in the Baltic region, on the one hand, by providing security guarantees to Lithuania, Latvia and Estonia, on the other - by expecting the newcomers to be reliable partners and supporters of US interests.

The changing American attitude towards Lithuanian defence potential most obviously reveals US recommendations on major issues of Lithuanian defence policy. In 1997-1998 groups of experts from the US State and Defense Departments led by Major General Kievenaar carried out "Lithuanian Defense Assessment" where the US expressed its recommendations on the development of national armed forces. ${ }^{51}$ On Lithuania's request a similar study was made again in $2001 .{ }^{52}$

A comparative analysis of both documents illustrates different approaches of the US towards Lithuania and the capabilities the US thinks Lithuania can provide to its allies. The first study clearly advocated the principle of territorial defence and a big force structure that comes with this principle. The Assessment gave only short notices about the capabilities Lithuania could offer to peace support operations or NATO Art.5 operations; Host Nation Support (HNS) issues were not mentioned at all. The US recommended to allocate resources to strengthen national defence capabilities indicating that in case of aggression Lithuania should rely only on its own armed forces.

The study carried out in 2001, showed a completely different approach towards the Lithuanian armed forces. The study provides a detailed assessment what Lithuania could offer to the US and NATO, what set of capabilities and infrastructure could be used for the purposes of the Alliance. A huge attention is paid to C3I (command, control, communications, intelligence), interoperability with NATO, English language knowledge, HNS and to Klaipeda sea port and Zokniai airbase in particular. The study does not mention the model of territorial defence and expresses doubts about the static force structure - the US urges to create forces interoperable with NATO.

The changing attitude towards the Lithuanian defence model shows that the US started to consider Lithuania as a reliable partner able to participate in international US-led missions. A shift from territorial defence to more mobile deployable units and emphasis on HNS provides clear indication for Lithuania that in case of aggression it will not be left alone. So far, the US has not presented a concrete plan of

\footnotetext{
${ }^{51}$ Office of the Assistant Secretary of Defense for International Security Affairs and the United States European Command Lithuanian Defense Assessment, 1998.

${ }^{52}$ Office of the Secretary of Defense. International Security and European Policy. Strategic Review of the Defense Plans and Military Capabilities of the Republic of Lithuania, 2001.
} 
action on how the Alliance could defend Lithuania, but preliminary thinking is already under way.

The increasing US commitment to our region reflects diminishing costs of US engagement to Lithuania and its Baltic neighbours. These costs could be roughly divided into three groups:

tical. They derive from the negative Russian and Byelorussian reaction to US engagement.

Mili-

tary. Military costs are associated with the demonstration of US readiness to defend the Baltics.

F i -

nancial. It includes direct transfer of funds to the Baltic states.

The changing relationship of Russia with Europe and the US decreases costs for effective deterrence in the Baltic region. First of all, it affects political costs of American engagement. It is not a secret that the failure of Lithuania, Latvia and Estonia during the first wave of NATO enlargement was a direct consequence of prospective political costs associated with Baltic NATO membership. The logic of the Russia first approach assumed that the invitation of Lithuania could have negative consequences for democracy in Russia, and would bring Russia back to authoritarism or even confrontation between the former Cold War adversaries.

A similar logic was heard, albeit on a smaller scale, before the second wave of NATO enlargement. Already before the September 11 events, on September 3, the Russian President Putin stated in Helsinki that he believed it was up to the Baltic States to decide whether to join or not although he saw no particular reasons for that. ${ }^{53} \mathrm{~A}$ shift in Russian priorities and the emerging strategic partnership with the US solved the dilemma of "unbearable costs" of being in the Baltics and made it more acceptable for American decision-makers.

NATO membership will make deterrence more robust and reliable, however, already now, according to L.Wallin, "all Partner Countries have the right to demand consultations according to Article 10 of the Partnership Agreement. In addition, armed aggression would carry a very high political - and economic - price." ${ }^{54}$ Furthermore, in soon Lithuania, Latvia and Estonia will become EU members. This would further increase political and other costs of aggression. The EU could not passively watch a member state being attacked without jeopardizing its own future.

If negative developments in Russia lead to a situation in which radical or extremist attitudes become dominant, the deterrence effect of Baltic NATO membership should reduce the risk of Russian aggression in the Baltic Sea area. This

\footnotetext{
${ }^{53}$ Gorenburg (note 40), p.27

${ }^{54}$ Wallin (note 44 ).

${ }^{55}$ Institute for Foreign Policy Analysis (note 36), p.3.
} 
means that Baltic membership would tend to increase the security of all Europe, concludes L.Wallin.

A hypothetically worst-case scenario in greater detail was presented in the study Strategic and Operational Implications of NATO Enlargement in the Baltic Region prepared by the Institute of Foreign Policy Analysis. They concluded that "should a worst-case scenario play out, the operational requirements for NATO and U.S. forces are likely to be similar to those that they would need to respond to a major threat in another theater, such as the Persian Gulf. These would include core warfighting capabilities such as strategic lift, rapid reaction forces, the ability to deliver massed air-to-ground strikes in the early stages of a conflict, air-to-ground surveillance, and special operations forces (SOF)." 55

According to the IFPA, the United States is likely to be the prime supplier of both the allied air support and special operational forces units. The present capabilities of the US would allow it to fulfil its commitments, but it is worth considering that the ability of the United States to respond could be taxed if US forces were engaged elsewhere in another major operation.

The main conclusion from the operational study on Baltic defence assumes, that "as long as Russia confines itself to conventional options, the prospects for successfully defending the Baltic states under worst-case scenarios are good. However, the defensive equation becomes complicated when the potential for Russian use of weapons of mass destruction is considered." 56 The IFPA assumes that a hostile regime willing to attack the Baltic states outright, in all likelihood, would not limit itself to conventional options. At the very least, Alliance and Baltic defence planners should not rule out the prospect of Russian WMD employment simply because it would violate international norms or risk provoking a broader conflict.

The issue of defensibility of the Baltic states is not frequently raised in official or academic circles, no public publications are available on this subject. However, during unofficial discussions several basic models for Baltic defence come out. The first option could be labelled as "the Polish model". It is premised on the existence of a sufficient base of indigenous forces that would be reinforced in a crisis from the outside. This model requires Lithuania to develop, or allies to be ready to rapidly deploy, to Lithuania a considerable quantity of conventional armaments (tanks, artillery, armoured combat vehicles, attack helicopters, fighters). In the second, "technological”, model reinforcements would come from 'over the horizon'. They would be largely based on American air power and precision guided munitions. The third option is a hybrid model which rests upon the employment of modest reinforcements, but would also include "over the horizon" air strikes. In theory, there exists deterrence by the retaliation model. Attacks would be carried out against the aggressor's civilian and economic targets using WMD.

All options have a different level of support in the US and among its allies and new members of NATO. It is clear that deterrence by the retaliation model would draw least support among all nations and the Baltic states. The US might prefer the "technological" model, assuming that financial costs associated with this model would be modest and the capabilities required already exist. The technological model is not acceptable for the Baltic states, because it rests only upon political US commitment

\footnotetext{
${ }^{56}$ Ibidem.
} 
and does not assure its physical presence in the region.

European NATO members would prefer the traditional "Polish" model. For Lithuania it would mean the creation of large territorial forces able to conduct largescale operations inside the country, but barely able to participate in "out of area" NATO operations. Considering that NATO nations are moving towards small, mobile and rapidly deployable units, the territorial defence model does not seem to be a feasible model for the Baltic states.

Most likely, the final decision will reflect a compromise between the needs of the Baltic states and capacities of the allies. Such compromise means that reinforcements would come from European NATO members and from the US. The hybrid model guarantees that deterrence would include the elements of the inevitability of defence and retaliation. For Lithuania it means that deterrence would be highly enhanced by the physical presence of the US in the region. This presence might be manifested in the form of common initiatives, military training or exercises or even permanent location of US troops.

Additional costs for NATO enlargement arise from Russian policy to minimise the consequences of US engagement in the Baltic region. First of all, Russia seeks to establish political and legal limitations for America's presence. In real terms, this means that the US will be denied the opportunity to deploy nuclear weapons and establish military bases on the territory of new NATO members. Secondly, the existing arms control regime will be extended to the Baltic states. Already in 1993, Lithuania joined the Vienna Document on confidence and security building measures and exchange of military information. In the 1999 Istanbul Summit, Lithuania declared that it was considering the possibility of the accession to the CFE Treaty, provided the accession terms were in Lithuania's national interests. In September 2002, the President of Lithuania in his statement before the UN General Assembly reaffirmed the intention to accede to the CFE Treaty after the adapted treaty comes into force and is open to all European democracies. In addition, in 2002, Lithuania applied for membership in the Open Skies Treaty, and the Open Skies Commission at the OSCE approved the Lithuanian application. The Open Skies Treaty creates the regime for aerial observation, which aims to improve openness and transparency among state parties.

These measures diminish the reliability of deterrence since they put limitations on the presence of the Alliance on the territory of the new members. Most likely, because of political considerations, the US and other allies will be willing to pay this price. Arms control regime and limitation of troops in this sensitive area will provide additional guarantees to Russia that in times of crises no huge military potential would be concentrated in the Baltic states. These are political costs and they make a significant part of the NATO enlargement process.

US financial costs originating from its engagement in the Baltics are relatively small. The military integration of the new members of 1999 has proved to be more difficult than expected. According to L.Wallin, "insufficient knowledge of English within their militaries, slow progress in reforming defence structures and planning, insufficient resources to bring about the necessary modernization of their NATO incompatible materiel, and the unreformed attitudes and outmoded operational con-

\footnotetext{
${ }^{57}$ Wallin (note 44).

${ }^{58}$ Wilk A. The new members of the new NATO, Centre for Eastern Studies, Warsaw, http:// www.osw.waw.pl/en/epub/eRap2002/ecz_01.htm
} 
cepts still prevalent in their officer corps are often quoted examples of obstacles to integration. In most, or all, of these respects the Baltic states have an advantage compared to the new members of 1999 as well as to their fellow candidates." 57

A.Wilk in his report "The new members of the new NATO", written for the Center for Eastern Studies, emphasized that "since armies [of the Baltic states] were created from scratch in the 1990s (without any old equipment and materiel), they did not have any significant problems with adjusting themselves to the NATO standards expected of them. (The up-to-date materiel and equipment were usually presented to them by the Western countries.) A considerable increase in the expenses for the modernisation of the armed forces is of large significance here. In the case of joining NATO, the three Baltic countries (as the only candidates so far) would have the armies already adjusted to its standards." 58

NATO expects from the invitees to develop small and mobile forces, that could contribute to collective defence. On the other hand, according to the report by the Centre for Naval Analysis, "despite their relatively advanced state of preparation, the Baltic States' small size and limited resources mean that they will never be significant contributors to NATO military forces. Their air forces are entirely dedicated to surveillance, with no attack and limited air defense capability. Their armies are currently capable of fielding no more than one NATO-interoperable battalion per country, although there are plans to increase this to a brigade per country by $2006 . " 59$ Despite their small size, the Baltic States could provide capabilities that would enhance NATO's military capability. The CNA stressed that "most important, their inclusion will extend NATO's air surveillance system to cover the entire Baltic Sea and a large part of northwestern Russia." ${ }^{60}$

The Institute of Foreign Policy Analysis emphasises another aspect of BALTNET's integration which is important for the US. "Collectively, all three Baltic nations comprise a cohesive strategic space that has particular relevance for integrated air and missile defense operations and the defense-in-depth of Northern European Alliance territories. “61 In 2002, Lithuania, Latvia and Estonia announced that they were procuring new radars for the BALTNET - Lithuania decided to obtain two middle-range, Latvia and Estonia opted for one long range radar each. These plans have already triggered a negative reaction in Russian mass media, which claim that data from new radars could be transferred to American intelligence networks or the BALTNET could be plugged into the missile defence system.

Overall, the CNA emphasised that, in their estimation, when the probability of military aggression is very small, US costs associated with their integration are negligible. The CNA concludes that "the strategic benefits of the membership for the Baltic states outweigh the majority of concerns related to worst-case scenarios." 62

From this perspective, the integration of small but modern Lithuanian, Latvian or Estonian armed forces represents a small financial burden for both the applicants and the Alliance. The International Monetary Fund in its study "The Baltics:

\footnotetext{
${ }^{59}$ Gorenburg (note 40), p.11

${ }^{60}$ Ibidem, p.2

${ }^{61}$ Institute for Foreign Policy Analysis (note 36), p.4.

${ }^{62}$ Ibidem, p.1.

${ }^{63}$ International Monetary Fund The Baltics: Medium - Term Fiscal Issues Related to EU and NATO accession, 2002, p.3-4.

${ }^{64}$ Official information form Lithuanian Ministry of National Defence, International Relations Department.
} 
Medium-Term Fiscal Issues Related to EU and NATO accession" has pointed out that "the Baltics are well placed to face the fiscal challenges of the EU and NATO membership. With modern tax and expenditure structures at the outset and a long tradition of prudent fiscal policy to support the maintenance of their exchange rate regimes, they can be expected to embrace these challenges in the years ahead." ${ }^{63}$

The US provides Lithuania with financial assistance that is used to prepare its armed forces to integrate into NATO. The International Military Education and Training (IMET) programme was created to support the training of Lithuanian military personnel in US educational institutions. In 1995, Lithuania received 200,000 USD, in 1996 - 498,000 USD, in 1997 - 520,000 USD, in 1998 m. - 650,000 USD, in 1999 m. $-727,000$ USD, in 2000 - 760,000 USD, in $2001 \mathrm{~m}$. - 800,000 USD support. ${ }^{64}$

Foreign Military Finance (FMF) funds were used to procure from the US military equipment for the Lithuania armed forces. In 1996, FMF funds amounted to $1.25 \mathrm{mln}$. USD (among many other items used mainly for the procurement of tactical communications equipment), in $1997-1.5 \mathrm{mln}$. USD (tactical communications equipment), in 1998 m. - 5.7 mln. USD (equipment for Regional airspace control centre, Military Cartography Centre), in 1999-4.7 mln. USD (equipment for Military Cartography Centre, the joint Lithuanian-Polish battalion), in $2000-4.4 \mathrm{mln}$. USD (equipment for Regional Airspace Control Centre, communications equipment), in $2001 \mathrm{~m}$. $-6.5 \mathrm{mln}$. USD (antitank systems, communications equipment). ${ }^{65}$

From the overview of the US support, a conclusion could be drawn that for political support and security commitments to the region, the US has acquired reliable and pro-American partners, that have resources and the political will to act as US allies and support its European policy. The Baltic states do not expect that for the sake of their freedom the US would sacrifice its global security interest, but they feel that they play quite an important role in US European strategy. The decreasing costs of American engagement in the Baltic region and the increasing weight that the Baltics will exercise in European politics could lead to increasing US commitments and activism in the region.

\section{Future Areas of Cooperation}

American policy towards Lithuania is part of a broader American global strategy directed at Europe and at CE and Northern Europe in particular. Lithuania's location of being in the middle of the pro-American part of Europe and the specifics of its geostrategic situation (borders with Belarus and the Russian Kaliningrad district) imply certain differences from the rest of the region.

First of all, Lithuania plays a more important role in constructing Western policy towards Belarus. Lithuania and Poland maintain much closer contacts with the Byelorussian position and opposition than the rest of Europe. The Lithuanian role will further increase when a regime change will take place in Belarus.

Secondly, Lithuania could play a more important role in the efforts of Western countries to integrate Russia into Europe. Lithuania, as the biggest investor in Kali-

${ }^{65}$ Ibidem. 
ningrad district, could contribute to the transformation of this Russian district into a model for future cooperation between NATO and EU members and the country that strives to get closer to both organisations.

Despite national peculiarities, Lithuania will maintain its regional role in US global strategy. European policy and transatlantic relationship remains the main items on their agenda. Together with other countries in the CE and Northern European region, Lithuania is interested to keep American engagement in the region, transform NATO into a more effective organisation, help Russia become a democracy with market economy, keep the EU away from creating a military dimension. Concurrence of interests makes the US and countries of the CE and Northern European region natural partners on most European policy issues.

At the beginning of 21st century, the US seeks to transform CE and Northern European region into a secure and stable zone. However, in the future, the US could decide that its all objectives in CE and Northern European have been accomplished and it could, with minimal financial implications, maintain status quo in this part of Europe. In such scenario, the Baltic states would become a part of a quiet and godforsaken corner of Europe. The US could decide that all problems have been solved and decrease its engagement in the region.

Such scenario would run counter Lithuanian interest. US disengagement would mean the return of German-Russian domination and leave less flexibility for decisionmakers in Vilnius. Therefore, Lithuania must find areas where it could be useful to Americans and would draw US interests into the region. The CSIS emphasised that "Lithuania can strengthen American interests in Europe by acting as a reliable U.S. ally within the Alliance and promoting Washington's interests in security, trade, and business. Lithuania has the political will to use its diplomatic, economic, and military resources to this effect." ${ }^{66}$ Lithuania and other countries of the region must find niches where they could specialise and where their activities could play an important role in US global strategy.

\begin{tabular}{llllll}
\hline & $\begin{array}{l}\text { Russia, } \\
\text { Kaliningrad }\end{array}$ & Belarus & Ukraine & Central Asia & Antiterrorism \\
& big & big & middle & small & middle \\
Northern Europe & middle & middle & small & small & small \\
Baltic states & middle & small & middle & small & middle \\
Vilnius 10 & middle & small & small & small & small \\
Lithuania alone & &
\end{tabular}

The most promising way is regional cooperation. CE and Northern Europe is a region of small states. Even larger countries as Sweden and Poland alone are not significant actors on the international arena. Only acting together, small CE and Northern European countries can develop important capabilities.

The US has always supported all forms of regional cooperation in the region. The Council of the Baltic Sea, the BALTSEA Forum, V10 Group, the Central European Initiative and other ideas have received warm responses from the US administration. From the point view of the US, two aspects are important. First, new initiatives must not lead to regionalisation of security. Secondly, initiatives must not contradict US foreign policy objectives. Here, Lithuania can play an important role in

\footnotetext{
${ }^{66}$ Center for Strategic and International Studies (CSIS), Institute of International Relations and
} Political Science, Vilnius, (note 2), p.60. 
working together with its partners in order to increase its role in certain areas:

By acting together, the countries will not only achieve their national objectives but also gain financial and political US support and greater attention in Washington. To achieve this, the initiative must be based on several principles:

• ............................................................................................................. i must lead to the creation of real capabilities that could be used by the partners; - ...................................................................................................... $\mathrm{t} h \mathrm{e}$ initiative must embrace Russia, the Ukraine, or perhaps, in the future, Belarus;

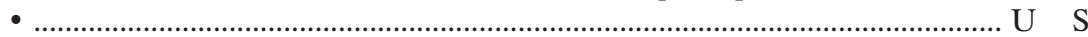
participation costs must be kept at the lowest possible level;

......t h e result of the initiative must add value to the antiterrorist campaign or to the

\begin{tabular}{|c|c|c|c|}
\hline Interests & USA & Lithuania & $\begin{array}{l}\text { Lithuania's role in US } \\
\text { strategy }\end{array}$ \\
\hline Global & $\begin{array}{l}\text { Maintain hegemony; } \\
\text { war against terrorism, } \\
\text { fight against } \\
\text { proliferation of WMD }\end{array}$ & $\begin{array}{l}\text { Has no independent } \\
\text { agenda, low priority }\end{array}$ & $\begin{array}{l}\text { Lithuania as US force } \\
\text { multiplier }\end{array}$ \\
\hline European & $\begin{array}{l}\text { Fix Russian borders, } \\
\text { strengthen NATO, } \\
\text { maintain balance of } \\
\text { power, non-militarised } \\
\text { EU }\end{array}$ & $\begin{array}{l}\text { Similar to the US but } \\
\text { more emphasis on } \\
\text { intra-EU issues }\end{array}$ & $\begin{array}{l}\text { Huge opportunities for } \\
\text { cooperation in } \\
\text { constructing policy } \\
\text { towards Russia and } \\
\text { coordinating positions } \\
\text { on intra-EU issues }\end{array}$ \\
\hline Regional & $\begin{array}{l}\text { Not high priority, } \\
\text { mainly concerning } \\
\text { common principles, } \\
\text { such as democratic } \\
\text { values }\end{array}$ & $\begin{array}{l}\text { Democracy in Belarus, } \\
\text { demilitarisation and } \\
\text { economic development } \\
\text { of Russia }\end{array}$ & $\begin{array}{l}\text { Lithuania is interested } \\
\text { to involve the US into } \\
\text { regional matters in } \\
\text { exchange of its support } \\
\text { on global policy issues. }\end{array}$ \\
\hline
\end{tabular}

development of democratic societies in other regions.

Forums or initiatives that meet these criteria exist already. $5+3+1$ meeting of Defence Ministers where major issues of Northern European security are discussed can be a good example of this. This forum should be maintained or even transformed to include the implementation of concrete military projects.

The main challenge that lies ahead is to combine these principles with national priorities. Lithuania, as a future member of the EU, will take into account common positions in the framework of CFSP, which sometimes differ from US suggestions. The US, as the world's dominant power, and Lithuania, as a small state, naturally have different priorities in the world, in Europe and its northern part. Lithuania will pay its attention largely to regional problems, intra-European issues will gain more importance, whereas global issues as terrorism, proliferation of WMD, global stability will dominate the US agenda.

The Institute of Foreign Policy Analysis concluded in a similar way by saying

${ }^{67}$ Institute for Foreign Policy Analysis (note 36), p.5. 
that "the United States has exerted a fair amount of political capital to make Baltic membership in NATO a reality. It is now the Baltic states' turn to repay the favor and prove that they are, in fact, members of the Euro-Atlantic family, ready and willing to continue to contribute their resources and personnel to the defense of common interests. ${ }^{97}$ According to the IFPA, the Baltic states can do this in three ways.

First, they must continue the serious work of preparing and improving their militaries for operations with the Alliance. Expediting and expanding plans and facilities for Host Nation Support (HNS) should be a priority in this regard, as should the development of effective capabilities for operating in crisis response scenarios.

Second, the Baltic states must enhance their efforts to reach out to Russia. The confidence that NATO's security guarantee provides should make it easier for them to engage their larger neighbour. Lithuania could serve as a bridge between Russia and the Alliance.

Finally, the Baltic states must recognize that as full NATO members, they will have a meaningful voice in the debates and discussions on key matters of the Alliance's business. They must use this voice to support the transformation of the Alliance so that it would remain a viable defence organisation.

The US is waiting for partners' contribution in transferring common democratic values to other regions that still suffer from instability, extremism and terrorism. After Lithuania regained its independence in 1990, it received a huge support from its northern neighbours. Now, it's Lithuania's turn together with other nations to support countries in the Caucasus, the Balkans or Central Asia. Its efforts in these regions would draw significant support from the US.

From the global perspective, Lithuania should enhance its cooperation with US allies in more distant parts of the world. Defence and security related cooperation with Middle East countries (Israel, Jordan, Egypt) or South Asia (Pakistan, Afghanistan) could have a positive impact on Lithuania's security cooperation with the US.

In its efforts to maintain American interest, areas that involve Russian or Ukrainian participation are especially promising. Examples of such cooperation might be common projects in Kaliningrad district covering different themes - science, environmental protection or crisis management. In the future, they can be extended to cover even military projects or initiatives. An example of similar cooperation might be the Kiel initiative which is aimed at fostering cooperation between the Navies of all Baltic Sea countries. Successful sea demining operations have already been conducted under the flag of this initiative.

Similar priorities between the US and Lithuania will remain in the future. The US will carry on with its vision - to create a stable and democratic region where friendly and prosperous nations prevail. They are bound by common values, beliefs and wish to expand the zone of democracy and free economy. During the last decade, Lithuania has achieved the status of an ally. The new status means not only privileges but also responsibilities. Security guarantees are the main expression of American interest. This is also a dividing line that separates the US-Lithuanian relations into two periods - prior to Prague and beyond.

Relations after Prague will take another character. NATO's business - adaptation of the Alliance, its internal reforms, out of area operations - will become a more important element of a bilateral dialogue. Membership in NATO and theNorth EU will also require that Lithuania formulate its position on such issues as Korea or Taiwan, which have never been Lithuania's priority. A larger spectrum of common challenges will further intensify the Lithuanian-American dialogue and will contri- 